\title{
COMMENTARY
}

\section{The good and the bad of diabetes mellitus in the critically ill}

\author{
Simon J Finney* \\ See related research by Siegelaar et al., http://ccforum.com/content/15/5/R205
}

\begin{abstract}
Diabetes mellitus is increasingly prevalent and associated with significant end organ damage that one may presume to impact upon critical illness. However, Siegelaar and colleagues present data that suggest, excepting those patients admitted to a cardiac intensive care unit, the presence of diabetes mellitus is not associated with increased mortality in critically ill patients. It is not possible to unpick how unmeasured parameters such as glycaemic control, the nature of whether type I or type II, or concomitant drug therapy confound the results. Nevertheless, the results are consistent with many risk-adjustment models used in the critically ill, and clinical practice that tolerates mild hyperglycaemia. Is it even possible that diabetes mellitus is protective?
\end{abstract}

The prevalence of diabetes mellitus is increasing, in part due to aging, obesity, and lower levels of physical activity. The findings of Siegelaar and colleagues presented in the previous issue of Critical Care challenge current beliefs but are also relevant to all [1]. Advanced diabetes is associated with end organ damage that is likely to impact upon critically ill patients - nephropathy, autonomic neuropathy, and small-vessel and large-vessel disease. Thus many believe that diabetes is associated with increased mortality and morbidity in patients admitted to an intensive care unit (ICU). Moreover, studies have demonstrated that not addressing severe hyperglycaemia ( $>10 \mathrm{mmol} / \mathrm{l}$ ) in critically ill patients is associated with higher mortality $[2,3]$.

Siegelaar and colleagues use meta-analysis techniques to examine the relationship between mortality and diabetes mellitus in patients admitted to an ICU. Pooling

*Correspondence: s.finney@rbht.nhs.uk; s.finney@imperial.ac.uk Adult Intensive Care Unit, Royal Brompton Hospital, Sydney Street, London SW3 6NP, UK data from 141 studies and nearly 12.5 million patients, they demonstrate that, outside the cardiothoracic ICU, diabetes mellitus is not associated with an increased risk of mortality. Their findings were consistent whether mortality was considered at ICU discharge, hospital discharge, or $28 / 30$ days.

The value of the study lies in the large number of patients included, sourced from a broad range of publications most of which were not specific to patients with diabetes mellitus. Moreover, the Forest plots demonstrate consistency between studies. However, unmeasured confounders may influence their results. Whilst a sensitivity analysis using risk-adjusted mortality from five studies encompassing $\sim 15 \%$ of the patients demonstrates a similar result, the model is not comprehensive. For example, patients with diabetes mellitus may receive inhibitors of the renin-angiotensin system, HMG-CoA reductase inhibitors, peroxisome proliferator-activated receptor gamma agonists, and aspirin. All of these treatments have been postulated to affect outcome in critically ill patients [4-6]. The study is limited also by considering diabetes mellitus as a homogeneous entity rather than a diagnosis that encompasses two different pathophysiologies and widely ranging therapies and qualities of glycaemic control. How all these parameters impact upon outcome is not explored.

The authors' results are mirrored in current riskadjustment models. In the cardiothoracic setting, the presence of diabetes mellitus has been used as a risk factor for perioperative mortality in the Parsonnet score [7] but not the EuroSCORE tools [8]. Cardiac revascularisation of patients with diabetes mellitus is complicated by poorer targets and microvascular disease. By contrast, diabetes mellitus does not form part of standard ICU risk-prediction models such as the Acute Physiology and Chronic Health Evaluation score and the Simplified Acute Physiology Score [9-12].

Why does the presence of diabetes mellitus not matter outside the cardiothoracic ICU? As the authors point out, the higher incidence of sepsis in patients with diabetes mellitus may imply a protective effect. Certainly, targeting mild hyperglycaemia in all patients seems 
preferable to strict normoglycaemia control [13]. The effects of insulin may be detrimental in the critically ill [14]. Insulin is anti-inflammatory [15] and switches cells to preferentially metabolise glucose rather than free fatty acids. Alternatively, patients with diabetes mellitus may be taking protective medications or have become accustomed to mild hyperglycaemia, a prooxidant status, or increased levels of advanced glycated end products - all implicated in the pathogenesis of systemic inflammation.

Since few would have cited diabetes mellitus as a contributory reason for defining an ICU admission as futile, Siegelaar and colleagues' study does not change our clinical practice. Nevertheless, the suggestion of a potential protective effect for diabetes mellitus merits further investigation. Unpicking this hypothesis may reveal new therapeutic strategies that we can exploit in other patient populations.

\section{Abbreviations}

ICU, intensive care unit.

\section{Competing interests}

The author declares that he has no competing interests.

Published: 12 December 2011

\section{References}

1. Siegelaar SE, Hickmann M, Hoekstra JBL, Holleman F, DeVries JH: The effect of diabetes on mortality in critically ill patients: a systematic review and meta-analysis. Crit Care 2011, 15:R205.

2. Van den Berghe G, Wilmer A, Hermans G, Meersseman W, Wouters PJ, Milants I, Van Wijngaerden E, Bobbaers H, Bouillon R: Intensive insulin therapy in the medical ICU. N Engl J Med 2006, 354:449-461.

3. Van den Berghe $G$, Wouters P, Weekers F, Verwaest C, Bruyninckx F, Schetz M, Vlasselaers D, Ferdinande P, Lauwers P, Bouillon R: Intensive insulin therapy in the critically ill patients. N Engl J Med 2001, 345:1359-1367.

4. Salgado DR, Rocco JR, Silva E, Vincent JL: Modulation of the reninangiotensin-aldosterone system in sepsis: a new therapeutic approach? Expert Opin Ther Targets 2010, 14:11-20.
5. Falagas ME, Makris GC, Matthaiou DK, Rafailidis PI: Statins for infection and sepsis: a systematic review of the clinical evidence. J Antimicrob Chemother 2008, 61:774-785.

6. O'Neal HR, Jr, Koyama T, Koehler EA, Siew E, Curtis BR, Fremont RD, May AK, Bernard GR, Ware LB: Prehospital statin and aspirin use and the prevalence of severe sepsis and acute lung injury/acute respiratory distress syndrome. Crit Care Med 2011, 39:1343-1350.

7. Parsonnet $V$, Dean D, Bernstein AD: A method of uniform stratification of risk for evaluating the results of surgery in acquired adult heart disease. Circulation 1989, 79(6 Pt 2):13-112.

8. Nashef SA, Roques F, Michel P, Gauducheau E, Lemeshow S, Salamon R: European system for cardiac operative risk evaluation (EuroSCORE). Eur J Cardiothorac Surg 1999, 16:9-13.

9. Metnitz PG, Moreno RP, Almeida E, Jordan B, Bauer P, Campos RA, lapichino G, Edbrooke D, Capuzzo M, Le Gall JR: SAPS 3 - from evaluation of the patient to evaluation of the intensive care unit. Part 1: objectives, methods and cohort description. Intensive Care Med 2005, 31:1336-1344.

10. Moreno RP, Metnitz PG, Almeida E, Jordan B, Bauer P, Campos RA, lapichino G, Edbrooke D, Capuzzo M, Le Gall JR: SAPS 3 - from evaluation of the patient to evaluation of the intensive care unit. Part 2: development of a prognostic model for hospital mortality at ICU admission. Intensive Care Med 2005, 31:1345-1355.

11. Knaus WA, Draper EA, Wagner DP, Zimmerman JE: APACHE II: a severity of disease classification system. Crit Care Med 1985, 13:818-829.

12. Knaus WA, Wagner DP, Draper EA, Zimmerman JE, Bergner M, Bastos PG, Sirio CA, Murphy DJ, Lotring T, Damiano A: The APACHE III prognostic system. Risk prediction of hospital mortality for critically ill hospitalized adults. Chest 1991, 100:1619-1636.

13. Finfer S, Chittock DR, Su SY, Blair D, Foster D, Dhingra V, Bellomo R, Cook D, Dodek P, Henderson WR, Hébert PC, Heritier S, Heyland DK, McArthur C, McDonald E, Mitchell I, Myburgh JA, Norton R, Potter J, Robinson BG, Ronco $\mathrm{JJ}$ : Intensive versus conventional glucose control in critically ill patients. $N$ Engl J Med 2009, 360:1283-1297.

14. Finney SJ, Zekveld C, Elia A, Evans TW: Glucose control and mortality in critically ill patients. JAMA 2003, 290:2041-2047.

15. Hansen TK, Thiel S, Wouters PJ, Christiansen JS, Van den Berghe G: Intensive insulin therapy exerts antiinflammatory effects in critically ill patients and counteracts the adverse effect of low mannose-binding lectin levels. J Clin Endocrinol Metab 2003, 88:1082-1088.

doi:10.1186/cc10548

Cite this article as: Finney SJ: The good and the bad of diabetes mellitus in the critically ill. Critical Care 2011, 15:1018. 